University of Nebraska - Lincoln

DigitalCommons@University of Nebraska - Lincoln

\title{
Water use and yields of no-till managed dryland grasspea and yellow pea under different planting configurations
}

\author{
F.J. Calderón \\ M.F. Vigil \\ USDA-ARS \\ D.C. Nielsen \\ USDA-ARS \\ J.G. Benjamin \\ USDA-ARS \\ D.J. Poss \\ USDA-ARS
}

USDA-ARS, francisco.calderon@ars.usda.gov

Follow this and additional works at: https://digitalcommons.unl.edu/usdaarsfacpub

Part of the Agricultural Science Commons

Calderón, F.J.; Vigil, M.F.; Nielsen, D.C.; Benjamin, J.G.; and Poss, D.J., "Water use and yields of no-till managed dryland grasspea and yellow pea under different planting configurations" (2012). Publications from USDA-ARS / UNL Faculty. 839.

https://digitalcommons.unl.edu/usdaarsfacpub/839

This Article is brought to you for free and open access by the U.S. Department of Agriculture: Agricultural Research Service, Lincoln, Nebraska at DigitalCommons@University of Nebraska - Lincoln. It has been accepted for inclusion in Publications from USDA-ARS / UNL Faculty by an authorized administrator of DigitalCommons@University of Nebraska - Lincoln. 


\title{
Water use and yields of no-till managed dryland grasspea and yellow pea under different planting configurations
}

\author{
F.J. Calderón*, M.F. Vigil, D.C. Nielsen, J.G. Benjamin, D.J. Poss \\ Central Great Plains Research Station, USDA-ARS, 40335 County RD GG, Akron, CO 80720, USA
}

\section{A R T I C L E I N F O}

\section{Article history:}

Received 31 March 2011

Received in revised form 12 August 2011

Accepted 14 August 2011

\section{Keywords:}

Grasspea

Lathyrus

Pisum

Nitrogen

Water use efficiency

\begin{abstract}
A B S T R A C T
Grasspea (GP) (Lathyrus sativus) is a drought-tolerant legume that can be grown for forage and grain. It has potential value to be used as a nitrogen-fixing crop in dryland rotations with non-legume grain crops. However, the agronomy of GP for the Central Great Plains region have not been investigated. The objective of this research was to compare the grain and biomass yield, as well as $\mathrm{N}$ accumulation of GP relative to field pea (FP) in two planting configurations. We carried out a 3-year field experiment to compare dryland GP with Admiral yellow field pea (Pisum sativum) in two configurations: (1) a wide row spacing with lower population (WL) with $76-\mathrm{cm}$ rows with $75 \mathrm{~kg}$ seeds planted per ha, and (2) a narrower row spacing with a higher population $(\mathrm{NH})$ with $19-\mathrm{cm}$ rows with $136 \mathrm{~kg}$ seeds planted per ha. We measured the biomass, grain yield, $\mathrm{N}$ content, and soil water use. Our results show that the $\mathrm{NH}$ treatment out-yielded the WL treatment in both pea species. The GP had higher yield than FP on the lowest yielding year, while FP yielded better when overall yields were higher. Biomass production was also higher for the NH configuration, and GP was a higher biomass producer than FP over the 3-year study. The GP had higher N concentration in shoots and seed compared to FP, indicating higher N-fixing capacity. The FP matured faster than GP, and had marginally higher grain water use efficiency than GP. Our results show that GP is a viable alternative legume for the Central Great Plains, with comparable yields in low precipitation years. However, the longer growing season required by GP to mature has water use implications in years with reduced water availability in mid to late summer.
\end{abstract}

Published by Elsevier B.V.

\section{Introduction}

Early-seeded cool-season legumes are desirable for the Central Great Plains region because they avoid hot/dry weather during germination and grain filling, and are harvested early, before planting of the subsequent winter crop (e.g. winter wheat Triticum aestivum). Grasspea has been produced in Europe, western Asia, and Africa (Osman and Nersoyan, 1986), and could be a good alternative crop. The GP is considered drought resistant (Palmer et al., 1989), and during years of sparse precipitation GP is often one of the few crop species producing a harvestable yield. The water use efficiency of GP has been found to be greater than other legumes (Biederbeck and Bouman, 1994). However, GP seeds harbor several anti-nutritional factors, and also contain variable concentrations of a neurotoxin (Rao et al., 1964) so they should be consumed as part of a diverse diet.

Dryland agriculture in the Central Great Plains consists predominantly of winter wheat-summer fallow in which grain is harvested only every other year, allowing for soil water recharge during the

\footnotetext{
* Corresponding author. Tel.: +1 970345 2259; fax: +1 9703452088.

E-mail address: francisco.calderon@ars.usda.gov (F.J. Calderón).
}

fallow period. The main limiting factor for crop yields in this semiarid region is water, followed by $\mathrm{N}$ and $\mathrm{P}$ fertility. Soil recharge is not very efficient during the summer months of the fallow phase (Nielsen and Vigil, 2010), so it has been suggested that summer crops should follow wheat for a more efficient use of water (Peterson et al., 1996). Adding summer crops to increase the rotation intensity can have beneficial effects on soil quality, but there is a tradeoff in terms of wheat yields (Vigil and Nielsen, 1998). Water use by legume cover crops in semiarid areas can result in a subsequent decrease in wheat yield, resulting in a cost that is not offset by the $\mathrm{N}_{2}$ fixation benefit (Nielsen and Vigil, 2005). Legumes grown during what otherwise would have been a fallow period can cause a reduction of up to $1050 \mathrm{~kg} \mathrm{ha}^{-1}$ on subsequent wheat yield. This yield penalty, however, can be reduced if the cover crop or forage is terminated early, allowing for soil water recharge in late summer (Vigil and Nielsen, 1998).

Harvesting and selling peas as forage or grain rather than as a cover crop can offset some of the economic losses incurred due to depressed wheat yield. However, selling the forage or grain means that less $\mathrm{N}$ is returned to the soil, so there is a cost-benefit consideration to this practice. While the present situation is not favorable for cover cropping, the economics of $\mathrm{N}_{2}$ fixation may likely change in the coming years. Fertilizer price increases will eventually make 
crop rotations with $\mathrm{N}_{2}$-fixing legumes more economical, and interest in organic agriculture makes $\mathrm{N}_{2}$-fixation a desirable trait, even if all of the legume biomass is not completely returned to the soil as a cover crop. In addition to the fertilizer-savings benefit, replacement of fallow with a broadleaf crop can minimize the loss of soil through erosion. Because of this, dryland rotations containing peas can produce greater crop biomass and soil carbon compared to wheat-fallow (Sainju et al., 2007). In order to increase crop diversity, farmers should have at their disposal a variety of adapted legume species, so research about new legume alternatives is warranted.

While GP has been grown successfully in both the southern and northern plains (Rao et al., 2005; Rao and Northup, 2008), no studies about the agronomy of GP have been carried out under the challenging evaporative demand and low precipitation conditions found in the high Central Plains. Grasspea is commonly grown using $76-\mathrm{cm}$ row spacing in the cooler and wetter Northern Plains. However, in the high Central Plains, peas (Pisum sativum) are grown in narrower row spacing in order to achieve quick leaf area development and canopy closure for weed control. Previous studies on grasspea in Canada, Australia, and the US used row spacings that spanned from 18 to $60 \mathrm{~cm}$ (Biederbeck and Bouman, 1994; Rao and Northup, 2008; Siddique et al., 2001). Responses of legume performance to row spacing may be affected by plant variety (Grau et al., 1994), year/location (Lueschen et al., 1992), as well as tillage and planting time (Oplinger and Philbrook, 1992). These variations in row spacing and canopy density can enhance crop growth rate, dry matter production, and grain yield (Bullock et al., 1998; De Bruin and Pedersen, 2008). Row spacing, however, can have different effects on crop yields depending on the latitude (Lee, 2006), so the optimal row spacing for a particular geographic location needs to be determined. Water stress has also been shown to lessen the yield advantage of narrow row spacing (Devlin et al., 1995), so multi-year studies with varied precipitation are needed.

The objective of this study was to determine the production potential of GP on the High Plains based on measurements of dry matter production, seed yield, and water use efficiency in two different planting configurations, and in a side-by-side comparison with the more common FP.

\section{Materials and methods}

The research plots were established on a Weld loam (fine, smectitic, mesic Aridic Argiustolls) located at the USDA-ARS Central Great Plains Research Station $\left(40.15^{\circ} \mathrm{N}, 103.15^{\circ} \mathrm{W}\right)$. Prior to the experiment, four soil samples $(0-20 \mathrm{~cm}$ depth) were obtained from the research plots, sieved free of plant debris and rocks, and sent for analysis to Olsen's Agricultural Laboratory, Inc. (McCook, Nebraska). The soil had an average $\mathrm{pH}$ of 6.2 (1:1 suspension), 1.73

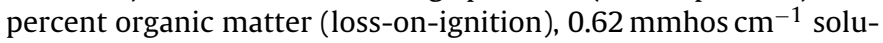
ble salts, 29.8 ppm bicarbonate $\mathrm{P}, 670.5 \mathrm{ppm} \mathrm{NH}_{4} \mathrm{Oac}$-extractable $\mathrm{K}$, and 36:39:25 sand:silt:clay content. The area is under a semiarid climate with nearly $420 \mathrm{~mm}$ average annual precipitation, at an elevation of $1384 \mathrm{~m}$ above sea level.

The GP and FP were planted on proso millet (Panicum miliaceum L.) residue in $4.5 \times 9 \mathrm{~m}$ plots within a randomized complete block design. There were four replications, two planting configurations ( $\mathrm{NH}$ and $\mathrm{WL}$ ) and two crop species for a total of 16 experiment plots each year. Each year the plots were moved into a new adjacent area in order to plant into millet residue. The GP cultivar was AC Greenfix (Dakota Frontier Seeds, Flasher, ND), and the FP cultivar was DS Admiral yellow pea. The seeds were coated with Micronoc dry inoculant (Texas Earth, Brownfield, Texas). The average (standard deviation) of the soil mineral $\mathrm{N}$ (ammonium plus nitrate $\mathrm{N}$ ) in the 16 experimental plots was $7.9(5.0) \mathrm{mg} \mathrm{N} \mathrm{kg}^{-1}$ at planting time in 2007, and no $\mathrm{N}$ fertilizer was applied during the 3-year experiment. The seeds were sown in early May each year, and the plots were harvested in July. Every year, Prowl (pendimethalin) herbicide was applied pre-emergence, and Select (clethodim) herbicide was applied to control grassy weeds. For the WL configuration, we used a MaxEmerge Plus Vacumeter planter (John Deere, Moline, Illinois, USA). For the $19-\mathrm{cm}$ rows, we used a John Deere 750 no-till grain drill. The in-row seeding density of the $76-\mathrm{cm}$ rows was maximized in order to lessen the population difference between planting configuration treatments. The $19-\mathrm{cm}$ rows had 14 seeds per meter length of row, while the $76-\mathrm{cm}$ rows had 31. At this seeding rates, the population of the $19-\mathrm{cm}$ row treatments was $136 \mathrm{~kg}$ seed ha ${ }^{-1}$, while that of the WL was $75 \mathrm{~kg} \mathrm{ha}^{-1}$. Because of the seeding population difference, this study cannot be seen as a strict comparison of two different row spacings, but rather as two different planting configurations that vary in their row spacing but have populations akin to what farmers would use for each row spacing setting.

\subsection{Soil water}

Soil profile water to 1-m depth was measured throughout the growing season. One Delta T PR2 Probe (Delta-T Devices Ltd., Cambridge, UK) access tube was installed in the middle of each of the 16 experimental plots, in the center of a planted row. Water use efficiency (WUE) was calculated as:

$$
\frac{\text { Crop yield }\left(\mathrm{kg} \mathrm{ha}^{-1}\right)}{\text { Water use }(\mathrm{mm})}
$$

where water use was estimated as stored soil water at planting minus ending water at harvest, plus growing season rain recorded at a weather station located $\sim 300 \mathrm{~m}$ from the site.

\subsection{Biomass and growth stage}

Plots were sampled periodically during the growing season by cutting a $122 \mathrm{~cm}$ length of row at ground level. Samplings were carried out approximately every two weeks in 2007 and 2008, but only the biomass at harvest was sampled in 2009. The biomass from each plot was placed in mesh bags, dried at $60^{\circ} \mathrm{C}$, and weighed.

\subsection{Yield and tissue $N$}

Plants were harvested at grain maturity and sampled in the same manner as for the biomass. The dry biomass was separated by hand into stems, leaves, seed, and pod shells. Harvest row segments were not adjacent to areas sampled for biomass earlier in the season. The pod shells + leaves + stems, without the grain, were pooled to constitute the plant sample for $\mathrm{C}$ and $\mathrm{N}$ analysis. Then, the plant and grain samples were ground separately with a Retsch mill (Retsch, Haan, Germany). Duplicate ground plant and grain samples from each plot were analyzed for total $\mathrm{C}$ and $\mathrm{N}$ concentration with a LECO CN-2000 analyzer (LECO Corporation, St. Joseph, MI).

\subsection{Soil mineral $N$}

Mineral N was analyzed at planting and at harvest in 2007, and also in May 2008 (pre-plant for the 2008 growing season), in order to measure differences in $\mathrm{N}$ supplying capacity for the different treatments. Mineral $\mathrm{N}$ was extracted from $10 \mathrm{~g}$ soil samples with $25 \mathrm{~mL}$ of $2 \mathrm{M} \mathrm{KCl}$. Nitrate $\mathrm{NO}_{3}-\mathrm{N}$ and ammonium $\mathrm{NH}_{4}-\mathrm{N}$ were determined using a Lachat Flow Injection Analyzer (Lachat Instruments, Loveland, Colorado). 


\subsection{Statistical analyses}

The 16 plots were placed on four randomized complete blocks. The design was relocated and randomized every year when the plots were established by no-till planting directly into the previous year's millet stubble. The Proc GLM of SAS 9.2 (SAS Institute Inc., Cary, NC) was used to perform ANOVA. The mean separations were carried out using Duncan's Multiple Range Test feature of SAS.

\section{Results and discussion}

\subsection{Soil water}

Growing season rainfall during the 3-year experiment ranged from 95 to $250 \mathrm{~mm}$, with the highest numbers each year for GP, due to the longer growing season (Table 1 ). The soil water difference between the first and last samplings of the season indicates the soil water extraction for each species, and was higher in GP than in FP for 2007 and 2008 (Table 1). Year 2009 was unusually wet and cool, with surplus water available to the crops as indicated by the larger amount of ending soil water relative to the previous years. 2008 had the lowest ending water, suggesting that this was the most water-limiting year of the experiment.

The difference between beginning soil water at planting and ending soil water had a year effect $(P<0.0001)$, and a marginally significant pea species effect $(P<0.10)$. The lowest values were recorded in 2009, because of high rainfall and cooler temperatures. The GP extracted more water than FP in the drier years of 2007 and 2008. However, most of the soil water extraction occurred from the $40-\mathrm{cm}$ depth and above, and there was little water extracted from $1 \mathrm{~m}$ soil depth in any of the treatments, even during the drier 2008 year (data not shown). These results agree with Biederbeck and Bouman (1994) who found that GP extracted water primarily from the top $0.6 \mathrm{~m}$ at the full bloom stage in Canada. However, they also observed that during a drought year, considerable water depletion occurred below $0.6 \mathrm{~m}$. Similar to our results, Siddique et al. (2001) found that GP and L. cicera had higher water extraction than $P$. sativum under conditions favorable for root penetration.

\subsection{Grain yield}

The ANOVA indicates that most of the variability in grain yields was due to planting configuration and year effects, not pea species (Table 2). Throughout the 3-year study, grain yields ranged from 716 to $2956 \mathrm{~kg} \mathrm{ha}^{-1}$, with the highest yields on the unusually wet 2009 summer (Table 3 ). The planting configuration effect was due to the large $95 \%$ increase in yields in the $\mathrm{NH}$ over the WL (Table 3 ). The species with year interaction (Table 2) occurred because GP had a higher yield than FP when grown as NH in 2008 (Table 3), the year with the least stored soil water (Table 1) and lowest yields. The highest yield for the experiment was achieved by the FP in $\mathrm{NH}$ during the high precipitation summer of 2009, suggesting that this species is more responsive to higher rainfall (Table 3). Others have found that $P$. sativum generally yields better than GP over a wide range of sites and years in a Mediterranean environment (Siddique et al., 1999). Our results indicate that GP and FP can out yield each other depending on environmental conditions, which in turn can vary widely in the high altitude, semiarid, continental climate of the Central Plains.

\subsection{Biomass yield}

Biomass at harvest followed similar ANOVA result patterns as the grain yield, except that there was a pea species effect besides the year and planting configuration main effects (Table 2 ). Biomass was $88 \%$ higher for the NH than the WL (Table 3), and the highest amounts occurred on 2009 (Table 4), as with the grain yield. This effect can be explained by the increased effectiveness of the tighter row spacing, and because of the higher population in the $\mathrm{NH}$. Biomass was $17 \%$ higher for GP than FP for the 3-year study (Table 3). In 2009, when FP grain yields outperformed GP, the biomass yield of GP was statistically higher than FP (Table 3 ). This indicates that the harvest index of GP was reduced in 2009 in both planting configurations (data not shown). Year 2009 had a wetter than average growing season, but most of the increased precipitation came in May and June, while July received only $48 \%$ of the $56 \mathrm{~mm}$ average for the location. We hypothesize that the GP harvest index is more sensitive to mid to late summer drought than the FP because of it's longer growing season.

\subsection{Grain and plant nitrogen}

Grain N, on a per ha basis, was affected by planting configuration and year, but not by species (Table 2). These large differences in grain $\mathrm{N}$ per ha (95\% higher in the $\mathrm{NH}$ over the $\mathrm{WL}$ ) are explained by the grain yield differences between row treatments (Table 3 ). Likewise, the grain $\mathrm{N}$ per ha was also largest in 2009 relative to the previous two years, mainly due to the overall greater yields in both pea species favored by the high rainfall (Table 3 ).

The amount of plant $\mathrm{N}$ per ha (which includes shoot plus leaves and grain pod shells) was affected not only by row treatment and year, but also by pea species (Table 2 ). The GP averaged $57 \%$ higher plant $\mathrm{N}$ per hectare compared to $\mathrm{FP}$, and this difference was pronounced in 2007 and 2009 (Table 3). The average increase in plant $\mathrm{N}$ due to the GP was $16 \mathrm{~kg} \mathrm{ha}^{-1}$ for the 3 -year study. The plant residue $\mathrm{N}$ left by the peas may have important implications for sustainable agriculture, because mineralization can supply $\mathrm{N}$ to the following crop (Heal et al., 1997). However, we observed that the aboveground pea biomass is prone to blowing away during the windy winters of the High Plains, so future research should investigate ways to keep the residue in place such as planting mixtures of peas with grassy crops. The planting configuration effect on plant $\mathrm{N}$ per ha was mainly due to the $67 \%$ increase in the biomass produced by the $\mathrm{NH}$ relative to the $\mathrm{WL}$ planting configuration (Table 3 ). As with the grain $\mathrm{N}$ per ha, 2009 produced the most plant $\mathrm{N}$ per ha relative to the other two years (Table 4 ).

The ANOVA indicates that there are pea species and year effects on the grain $\mathrm{N}$ percent, but planting configuration had no effect (Table 2). The GP had a $15 \%$ higher grain $\mathrm{N}$ concentration relative to FP in the 3-year study, averaged across both planting configurations (Table 5). The grain N percent was highest in 2008, the most water-limited year. Seed sink capacity can be negatively affected during drought, resulting in decreased accumulation of starch and oil. As drought stress increases, protein concentration increases in legumes such as soybean (Glycine max L. Merrill) (Dornbos and Mullen, 1992). Field observations showed that GP had more nodulation in the roots than the FP, although the difference was not quantified. This leads us to hypothesize that the greater $\mathrm{N}$ concentration in GP occurred because the GP fixed more N than the FP. Others have found that GP seed is particularly high in protein and lysine (Castell et al., 1994). Plant N percent, however, did not have year or row effects (Table 2), indicating that residue quality for the legume is not as affected as grain quality during low precipitation. The pea species effect was due to the overall $15 \%$ higher percent $\mathrm{N}$ content in GP plants relative to FP, which had differences in 2007 and 2009 (Table 5).

Grain C/N ratio had a year main effect according to the ANOVA (Table 2), but was not different between planting configurations or pea species. The grain $\mathrm{C} / \mathrm{N}$ was highest in 2009 (Table 4), suggesting that grain $\mathrm{C} / \mathrm{N}$ ratio increases when moisture conditions are conducive to higher yields. This is possibly due to a $\mathrm{N}$ 
Table 1

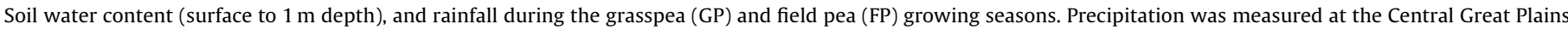

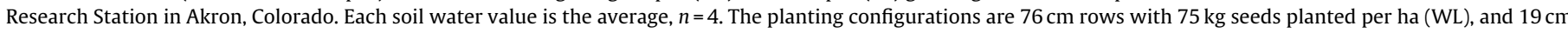
rows with $136 \mathrm{~kg}$ seeds planted per ha $(\mathrm{NH})$.

\begin{tabular}{|c|c|c|c|c|c|}
\hline & Planting configuration & Beginning soil water (mm) & Ending soil water (mm) & Difference (mm) & Growth season rain ${ }^{\dagger}(\mathrm{mm})$ \\
\hline \multicolumn{6}{|l|}{2007} \\
\hline GP & $\mathrm{NH}$ & 358 & 236 & 122 & 99 \\
\hline FP & $\mathrm{NH}$ & 379 & 304 & 75 & 95 \\
\hline GP & WL & 357 & 245 & 112 & 99 \\
\hline FP & WL & 323 & 252 & 71 & 95 \\
\hline \multicolumn{6}{|l|}{2008} \\
\hline GP & $\mathrm{NH}$ & 245 & 175 & 70 & 129 \\
\hline FP & $\mathrm{NH}$ & 255 & 194 & 61 & 103 \\
\hline GP & WL & 269 & 189 & 80 & 129 \\
\hline FP & WL & 260 & 207 & 53 & 103 \\
\hline \multicolumn{6}{|l|}{2009} \\
\hline GP & $\mathrm{NH}$ & 337 & 282 & 55 & 250 \\
\hline FP & $\mathrm{NH}$ & 319 & 255 & 64 & 208 \\
\hline GP & WL & 319 & 296 & 23 & 250 \\
\hline FP & WL & 365 & 315 & 50 & 208 \\
\hline
\end{tabular}

${ }^{\dagger}$ Because the GP has a longer season, slightly more rainfall accumulated with the GP than the FP.

Table 2

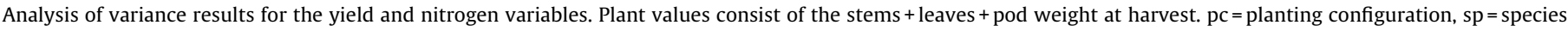
$\mathrm{yr}=$ year.

Grain yield Biomass at Grain N kg ha ${ }^{-1} \quad$ Plant $\mathrm{N} \mathrm{kg} \mathrm{ha}^{-1} \quad$ Grain N \% by weight Plant $\mathrm{N} \%$ by weight Grain C/N ratio Plant C/N ratio $\mathrm{kg} \mathrm{ha}^{-1} \quad$ harvest

\begin{tabular}{|c|c|c|c|c|c|c|c|c|}
\hline Pea species & NS & * & NS & $* * *$ & $* * *$ & $*$ & NS & $* * *$ \\
\hline Planting configuration & $* * *$ & $* * *$ & $* * *$ & $* * *$ & NS & NS & NS & NS \\
\hline Year & $* * *$ & $* * *$ & $* * *$ & $* * *$ & $* * *$ & NS & $* * *$ & $*$ \\
\hline Interactions & $\begin{array}{l}\text { sp. } \times \text { yr, } \\
\text { 3-way }\end{array}$ & $\mathrm{pc} \times \mathrm{yr}$ & sp. $\times$ yr & sp. $\times$ yr & None & sp. $\times$ yr & None & sp. $\times$ yr \\
\hline
\end{tabular}

${ }^{*} P<0.05$

${ }^{* * *} P<0.001$.

Table 3

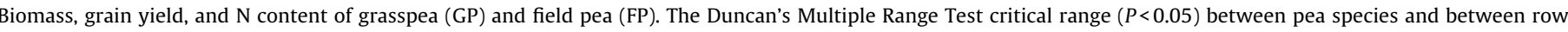
treatments is shown. The planting configurations are $76 \mathrm{~cm}$ rows with $75 \mathrm{~kg}$ seeds planted per ha (WL), and $19 \mathrm{~cm}$ rows with $136 \mathrm{~kg}$ seeds planted per ha ( $\mathrm{NH}$ ).

\begin{tabular}{|c|c|c|c|c|c|}
\hline & Planting configuration row spacing $(\mathrm{cm})$ & Grain yield $\left(\mathrm{kg} \mathrm{ha}^{-1}\right)$ & Biomass yield $\left(\mathrm{kg} \mathrm{ha}^{-1}\right)$ & Grain N (kg ha $\left.{ }^{-1}\right)$ & Plant $\mathrm{N}\left(\mathrm{kg} \mathrm{ha}^{-1}\right)$ \\
\hline \multicolumn{6}{|l|}{2007} \\
\hline GP & $\mathrm{NH}$ & 1722 & 4554 & 79.9 & 40.4 \\
\hline FP & $\mathrm{NH}$ & 1899 & 4570 & 73.9 & 27.0 \\
\hline GP & WL & 985 & 2603 & 46.9 & 22.6 \\
\hline FP & WL & 1049 & 2462 & 40.1 & 12.4 \\
\hline \multicolumn{6}{|l|}{2008} \\
\hline GP & $\mathrm{NH}$ & 1994 & 4315 & 93.3 & 26.9 \\
\hline FP & $\mathrm{NH}$ & 1065 & 2947 & 46.1 & 26.0 \\
\hline GP & WL & 738 & 1774 & 37.5 & 13.5 \\
\hline FP & WL & 716 & 1813 & 31.6 & 16.8 \\
\hline \multicolumn{6}{|l|}{2009} \\
\hline GP & $\mathrm{NH}$ & 2075 & 7650 & 90.2 & 77.6 \\
\hline FP & $\mathrm{NH}$ & 2957 & 6838 & 106.9 & 40.9 \\
\hline GP & $W L$ & 1245 & 4600 & 47.9 & 52.4 \\
\hline FP & WL & 1277 & 3189 & 47.6 & 25.6 \\
\hline \multicolumn{2}{|c|}{ Critical range between species or row treatments } & 249 & 503 & 10.3 & 7.0 \\
\hline
\end{tabular}

Table 4

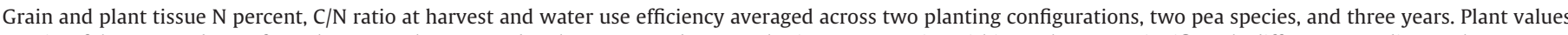

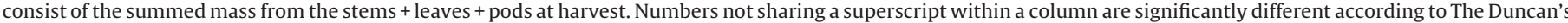
Multiple Range Test $(P<0.05)$.

\begin{tabular}{|c|c|c|c|c|c|c|c|c|c|c|}
\hline & Grain $\left(\mathrm{kg} \mathrm{ha}^{-1}\right)$ & Biomass ( $\mathrm{kg} \mathrm{ha}^{-1}$ ) & Grain $N\left(\mathrm{~kg} \mathrm{ha}^{-1}\right)$ & Plant N (kg ha $\left.{ }^{-1}\right)$ & Grain \% N & Plant \%N & Grain C/N & Plant C/N & $\begin{array}{l}\text { Grain WUE } \\
\left(\mathrm{kg} \mathrm{ha}^{-1} \mathrm{~mm}^{-1}\right)\end{array}$ & $\begin{array}{l}\text { Biomass WUE } \\
\left(\mathrm{kg} \mathrm{ha}^{-1} \mathrm{~mm}^{-1}\right)\end{array}$ \\
\hline 2007 & $1414^{\mathrm{b}}$ & $3548^{\mathrm{b}}$ & $60.2^{\mathrm{b}}$ & $25.6^{\mathrm{b}}$ & $4.3^{b}$ & $1.2^{\mathrm{a}}$ & $9.8^{b}$ & $39.1^{a}$ & $7.6^{a}$ & $18.8^{\mathrm{ab}}$ \\
\hline 2008 & $1128^{\mathrm{b}}$ & $2712^{c}$ & $52.1^{\mathrm{b}}$ & $20.8^{b}$ & $4.6^{\mathrm{a}}$ & $1.3^{\mathrm{a}}$ & $9.2^{\mathrm{b}}$ & $32.9^{\mathrm{b}}$ & $6.9^{a}$ & $15.6^{\mathrm{b}}$ \\
\hline 2009 & $1889^{a}$ & $5569^{a}$ & $73.1^{\mathrm{a}}$ & $49.2^{\mathrm{a}}$ & $3.9^{c}$ & $1.3^{\mathrm{a}}$ & $11.6^{\mathrm{a}}$ & $34.0^{\mathrm{ab}}$ & $6.4^{\mathrm{a}}$ & $20.1^{\mathrm{a}}$ \\
\hline
\end{tabular}

$\dagger$ Water use efficiency. 


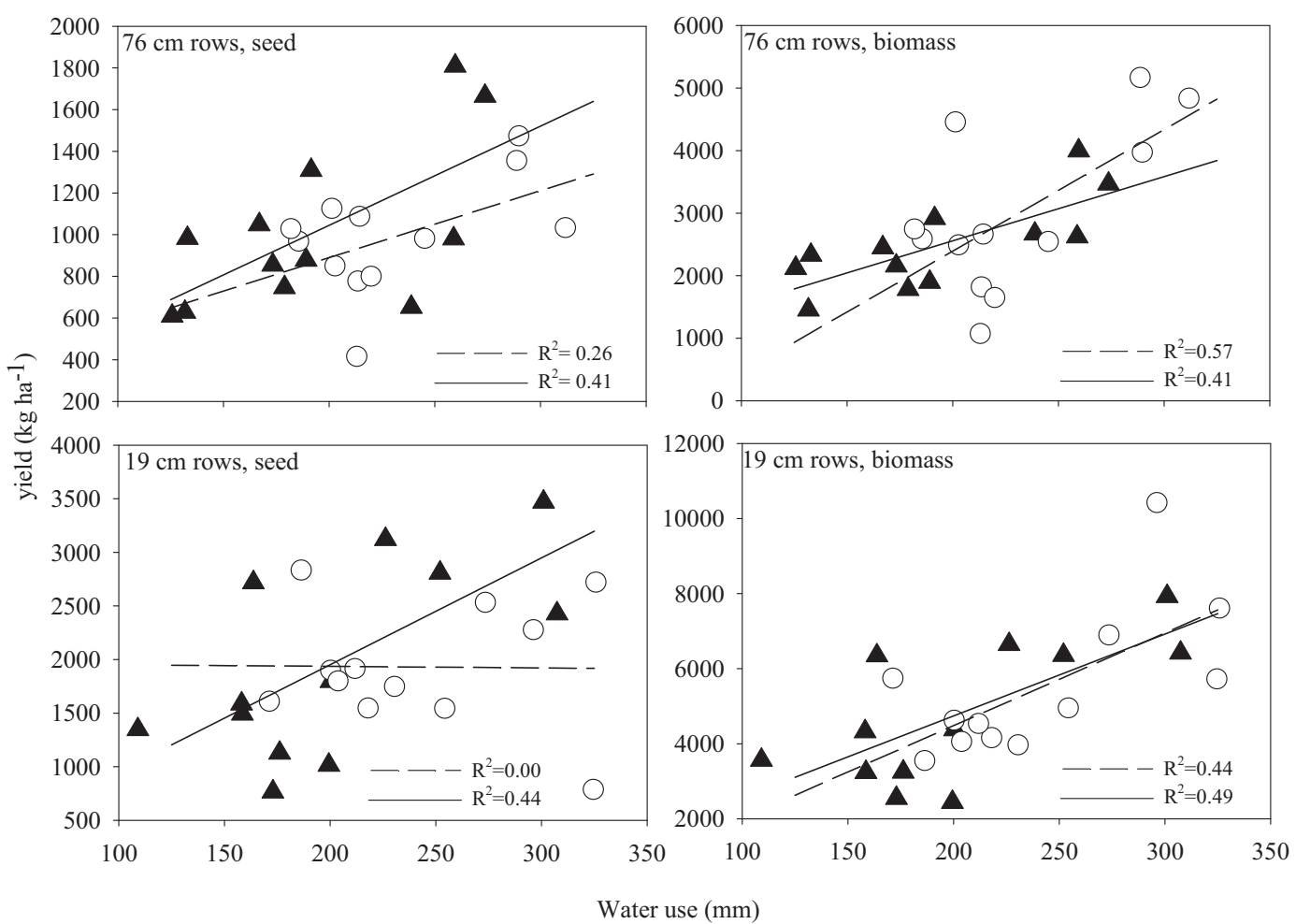

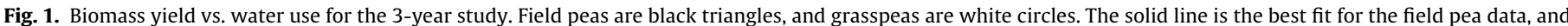

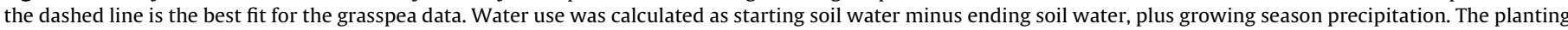
configurations are $76 \mathrm{~cm}$ rows with $75 \mathrm{~kg}$ seeds planted per ha, and $19 \mathrm{~cm}$ rows with $136 \mathrm{~kg}$ seeds planted per ha.

dilution effect from increased production of seed in wetter years. Plant $\mathrm{C} / \mathrm{N}$ was different between species, and there was also a year effect (Table 2). Contrary to the grain $\mathrm{C} / \mathrm{N}$, the plant $\mathrm{C} / \mathrm{N}$ ratio was not highest in 2009, but in 2007. This may be explained by the lack of a year effect on plant $\mathrm{N}$ percent. The plant $\mathrm{C} / \mathrm{N}$ ratios in this study ranged from 28 to 50 (Table 5 ). The FP plant $\mathrm{C} / \mathrm{N}$ ratio for the experiment averaged 39, compared to 32 for GP, and this difference was statistically significant. The higher residue quality of GP could lead to more mineralization and rapid N supply to subsequent crops (Heal et al., 1997). The potentially available $\mathrm{N}$ from crop

Table 5

Grain and plant tissue $\mathrm{N}$ percent and $\mathrm{C} / \mathrm{N}$ ratio at harvest between two pea species and two planting configurations. Grasspeas are (GP) and field peas are (FP). Plant values consist of the stems + leaves + pods. The Duncan's Multiple Range Test critical range $(P<0.05)$ between pea species and between row treatments is shown. Plant $\mathrm{N}$ refers to the shoot, leaves, and grain pod shells. The planting configurations are $76 \mathrm{~cm}$ rows with $75 \mathrm{~kg}$ seeds planted per ha $(\mathrm{WL})$, and $19 \mathrm{~cm}$ rows with $136 \mathrm{~kg}$ seeds planted per ha $(\mathrm{NH})$.

\begin{tabular}{lrrrr}
\hline \multicolumn{4}{c}{ Planting configuration $(\mathrm{cm})$ Grain N \% Grain C/N } & Plant N \% Plant C/N \\
\hline 2007 & 4.7 & 8.9 & 1.4 & 31.0 \\
GP NH & 3.9 & 10.7 & 1.0 & 44.7 \\
FP NH & 4.8 & 8.6 & 1.4 & 30.9 \\
GP WL & 3.8 & 10.8 & 0.9 & 49.7 \\
FP WL & & & & \\
2008 & 4.7 & 9.1 & 1.2 & 38.4 \\
GP NH & 4.4 & 9.7 & 1.4 & 32.2 \\
FP NH & 5.1 & 8.4 & 1.3 & 32.5 \\
GP WL & 4.4 & 9.6 & 1.5 & 28.6 \\
FP WL & & & & \\
2009 & 4.4 & 9.8 & 1.4 & 32.0 \\
GP NH & 3.6 & 11.7 & 1.1 & 41.8 \\
FP NH & 3.8 & 13.8 & 1.6 & 28.4 \\
GP WL & 3.8 & 11.2 & 1.3 & 33.9 \\
FP WL & 1.3 & 0.2 & 4.3 \\
Critical range between species or ro@ 2 & &
\end{tabular}

residues can reach nearly $60 \%$ of a cover crop total $\mathrm{N}$, and depends on the $\mathrm{C} / \mathrm{N}$ of the material (Vigil and Kissel, 1991). Incubation studies have tried to quantify the critical $\mathrm{C} / \mathrm{N}$ ratio of crop residues, i.e. the $\mathrm{C} / \mathrm{N}$ ratio where net $\mathrm{N}$ immobilization ends and $\mathrm{N}$ mineralization begins. While the critical $\mathrm{C} / \mathrm{N}$ ratios can be affected by incubation conditions, the critical value can reach 40 for long-term incubations (Vigil and Kissel, 1991). In this study, we show that the $\mathrm{C} / \mathrm{N}$ ratio of $\mathrm{FP}$ can surpass 40 , where mineralization potential is minimal (Table 5). This was not true of the GP, indicating that $\mathrm{GP}$ has the capacity to retain a favorable $\mathrm{C} / \mathrm{N}$ ratio for supplying $\mathrm{N}$ to a subsequent crop across different season precipitation regimes. Note, however, that mineral $\mathrm{N}$ (ammonium plus nitrate) measured in the fallow period after the 2007 season averaged $12 \mathrm{mg} \mathrm{kg}^{-1}$ for FP plots, while GP plots had an average of $17 \mathrm{mg} \mathrm{kg}^{-1}$. A second pre-plant sampling before the 2008 growing season showed that soil mineral $\mathrm{N}$ increased by less than $6 \mathrm{mg} \mathrm{kg}^{-1}$ during the fallow period, and while the net mineralization was overall small, it was larger on FP plots (data not shown). This suggests that the N supply to subsequent crops from these plots was minimized because much of the plant $\mathrm{N}$ was removed with the grain at harvest. Also, much of the above-ground pea residue was blown clear of the plots by winter winds. Because of this, we hypothesize that any pea $\mathrm{N}$ that may have accumulated due to mineralization in these plots would have come mostly from pea roots and soil organic matter.

\subsection{Water use efficiency}

There is a planting configuration effect $(P<0.0001)$ for both the grain WUE and biomass WUE. When averaged across species, the $\mathrm{NH}$ configuration had $89 \%$ and $81 \%$ greater grain WUE and biomass WUE than the WL configuration respectively (Table 6). Pea species had only a marginally significant effect on grain WUE $(P<0.10)$, and no statistical effect on the biomass WUE. However, both GP 
Table 6

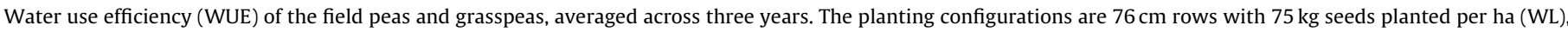
and $19 \mathrm{~cm}$ rows with $136 \mathrm{~kg}$ seeds planted per ha $(\mathrm{NH})$.

\begin{tabular}{|c|c|c|c|}
\hline & Row $(\mathrm{cm})$ & Grain $\mathrm{WUE}^{\dagger}\left(\mathrm{kg} \mathrm{ha}^{-1} \mathrm{~mm}^{-1}\right)$ & Biomass WUE ${ }^{\dagger \dagger}\left(\mathrm{kg} \mathrm{ha}^{-1} \mathrm{~mm}^{-1}\right)$ \\
\hline \multirow[t]{3}{*}{ Field pea (FP) } & $\mathrm{NH}$ & 9.8 & 24.0 \\
\hline & WL & 5.3 & 13.1 \\
\hline & Average & 7.5 & 18.6 \\
\hline \multirow[t]{3}{*}{ Grasspea (GP) } & $\mathrm{NH}$ & 8.3 & 22.8 \\
\hline & WL & 4.3 & 12.8 \\
\hline & Average & 6.3 & 17.8 \\
\hline GP and FP, NH average & & 9.1 & 23.4 \\
\hline GP and FP, WL average & & 4.8 & 13.0 \\
\hline
\end{tabular}

$\dagger$ The Duncan's Multiple Range Test critical range $(P<0.05)$ is $1.3 \mathrm{~kg} \mathrm{ha}^{-1} \mathrm{~mm}^{-1}$.

t† The Duncan's Multiple Range Test critical range $(P<0.05)$ is $3.1 \mathrm{~kg} \mathrm{ha}^{-1} \mathrm{~mm}^{-1}$.

and FP WUE should be considered relatively high. In a 6-year study in Canada, Biederbeck and Bouman (1994) found GP and feed pea to have high vegetative WUE (18 and $19 \mathrm{~kg} \mathrm{ha}^{-1} \mathrm{~mm}^{-1}$ respectively) compared to lentil, flatpea, vetch, and wheat. The GP had marginally less grain WUE than FP (Table 6), due to a longer season that resulted in higher precipitation values used for the WUE calculations. There was a marginally significant effect of year on biomass WUE $(P<0.10)$, but not on grain WUE. Biomass WUE, averaged across planting configurations and species, was highest $\left(20 \mathrm{~kg} \mathrm{ha}^{-1} \mathrm{~mm}^{-1}\right)$ in 2009 , the wettest year, and lowest in 2008 $\left(16 \mathrm{~kg} \mathrm{ha}^{-1} \mathrm{~mm}^{-1}\right)$. The WUE can be affected by the timing and amount of precipitation because of the dynamics of vegetative and reproductive development in legumes. For example, water stress during early vegetative growth results in short plants with reduced leaf area, which may then limit water extraction during reproductive growth (Nielsen and Nelson, 1998). More important is the water stress effect during reproductive development because it can curtail grain yield. Fig. 1 shows that the relationship between yield and water use is generally better for the biomass than for the grain. This is mostly due to variations in the harvest index across years. The relationship between biomass yield and water use shows that GP tends to perform similar to FP in NH configuration across a wide range of water usage (Fig. 1). However, on the WL configuration, FP has a higher corresponding yield than GP at the lower water usage values, which can be explained by the shorter season and the correspondingly less precipitation used for the water use calculations. Climate change models of the Central Great Plains Region predict increasing temperatures, higher evaporation rates, and more drought events (US Global Change Research Program). If these scenarios are realized, plants such as GP that can give reasonable yields during drought years, can become a good option for dryland farmers.

\subsection{Growth}

The GP and FP had marked differences in the timing of biomass accumulation, with biomass production occurring at a slower rate in GP (Fig. 2). Phenological development measurements taken in 2007 showed that FP reached the senescence at the same time that GP was still undergoing seed development with some pods still not reaching full length (data not shown). This meant that GP stayed in the field for approximately $15 \mathrm{~d}$ after FP harvest. The quantity and distribution of summer precipitation can vary between years in the Central Great Plains, which can result in stress during different developmental stages of a cool season crop. A terminal drought occurs when the legume lacks sufficient moisture during flowering and grain filling or when plants are seeded at the start of a droughty season (Frahm et al., 2004). The FP may be advantageous in a situation where the cool season legume is going to be followed by a winter crop, because it gives more time for soil water recharge, but this would only work when there is ample late summer

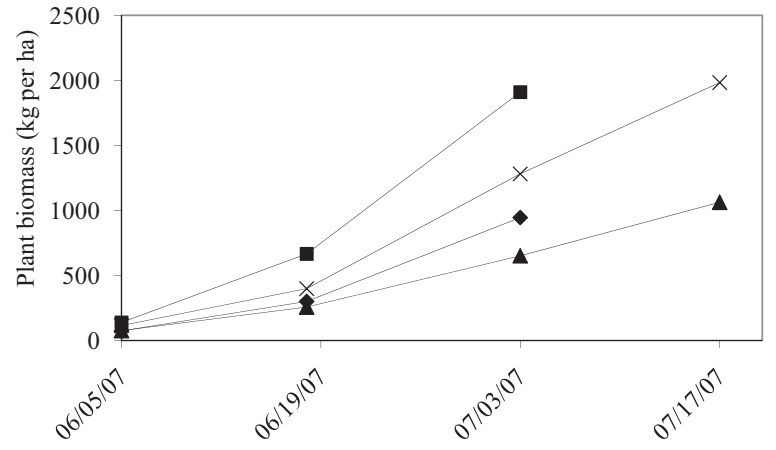

Fig. 2. Pea biomass measurements during the 2007 growth season. Admiral pea $19-\mathrm{cm}$ rows $136 \mathrm{~kg}$ seeds planted per ha ( $\mathbf{\square})$, admiral pea $76-\mathrm{cm}$ rows with $75 \mathrm{~kg}$ seeds planted per ha $(\bullet)$, grasspea $19-\mathrm{cm}$ rows $136 \mathrm{~kg}$ seeds planted per ha $(\times)$, and grasspea $76-\mathrm{cm}$ rows with $75 \mathrm{~kg}$ seeds planted per ha $(\boldsymbol{\Lambda})$. The values are averages, $n=4$.

precipitation. In addition, FP could be cut for forage at an earlier date than GP, for an equivalent amount of biomass (Fig. 2). Lyon et al. (1995) state that short-season summer crops use the initial stored soil water more effectively than long-season summer crops. Shorter season crops have more water available at grain-filling compared to long season crops, which use the initial soil water for vegetative growth instead of grain production. Water stress during flowering can negatively affect the number of pods, seeds per pod, seed yield, and seed weight (Singh, 1995; Nielsen and Nelson, 1998). This would imply that on years with good stored soil water but sparse summer rains, FP may be more competitive than GP. This, however, was not shown in 2007, a year with relatively high stored soil water and low summer rains, where FP and GP grain yields were statistically equal (Table 1 ).

\section{Conclusions}

Our research clearly shows that GP is a legume species well adapted to the climate of the Central High Plains, with comparable yields but longer season than the more common FP. Season length can be an important trait of adaptation in cool season legumes because early flowering can help avoid a late summer drought and the resulting lower grain filling (Siddique et al., 2001). The GP has somewhat lower grain WUE and leaves less precipitation recharge time for a subsequent winter crop compared to FP, which are important considerations for Central Great Plains dryland systems. The GP dried the soil more than FP during the growing season during the two driest years of the experiment. Grasspea had more biomass accumulation and $\mathrm{N}$ accumulation in the biomass and grain than $\mathrm{FP}$, indicating better $\mathrm{N}_{2}$-fixing capacity. The lower $\mathrm{C} / \mathrm{N}$ ratio and higher $\mathrm{N}_{2}$ fixation in GP can make it a more desirable choice as a cover crop than FP. Our results show that the $76-\mathrm{cm}$ row spacing recommended by GP seed suppliers leads to lower yields and biomass 
production in our geographic area. We have demonstrated that the $\mathrm{NH}$ planting configuration is more productive and suitable. One of the challenges of growing peas in the Central Great Plains region is weed control. We observed that regardless of planting configuration, tumbleweeds (Kochia scorparia, Salsola iberica) can become a problem in the late season unless good herbicide management is in place.

\section{Acknowledgements}

Mention of trade names or commercial products in this publication is solely for the purpose of providing specific information and does not imply recommendation or endorsement by the U.S. Department of Agriculture.

The U.S. Department of Agriculture (USDA) prohibits discrimination in all its programs and activities on the basis of race, color, national origin, age, disability, and where applicable, sex, marital status, familial status, parental status, religion, sexual orientation, genetic information, political beliefs, reprisal, or because all or part of an individual's income is derived from any public assistance program. (Not all prohibited bases apply to all programs.) Persons with disabilities who require alternative means for communication of program information (Braille, large print, audiotape, etc.) should contact USDA's TARGET Center at (202) 720-2600 (voice and TDD). To file a complaint of discrimination, write to USDA, Director, Office of Civil Rights, 1400 Independence Avenue, S.W., Washington, D.C. 20250-9410, or call (800) 795-3272 (voice) or (202) 720-6382 (TDD). USDA is an equal opportunity provider and employer.

\section{References}

Biederbeck, V.O., Bouman, O.T., 1994. Water use by annual green manure legumes in dryland cropping systems. Agron. J. 86, 543-549.

Bullock, D., Khan, S., Rayburn, A., 1998. Soybean yield response to narrow rows is largely due to enhanced early growth. Crop Sci. 38, 1011-1016.

Castell, A.G., Cliplef, R.L., Briggs, C.J., Cambell, C.G., Bruni, J.E., 1994. Evaluation of lathyrus (Lathyrus sativus L.) as an ingredient in pig starter and grower diets. Can. J. Anim. Sci. 74, 529-539.

De Bruin, J.L., Pedersen, P., 2008. Effect of row spacing and seeding rate on soybean yield. Agron. J. 100, 704-710.

Devlin, D.L., Fjell, D.L., Shroyer, J.P., Gordon, W.B., Marsh, B.H., Maddux, L.D., Martin, V.L., Duncan, S.R., 1995. Row spacing and seeding rates for soybean in low and high yielding environments. J. Prod. Agric. 8, 215-222.

Dornbos, D.L., Mullen, R.E., 1992. Soybean seed protein and oil contents and fatty acid composition adjustments by drought and temperature. J. Amer. Oil Chem. Soc. $69,228-231$.

Frahm, M.A., Rosas, J.C., Mayek-Pérez, N., López-Salinas, E., Acosta-Gallegos, J.A., Kelly,J.D., 2004. Breeding beans for resistance to terminal drought in the lowland tropics. Euphytica 136, 223-232.
Grau, C.R., Oplinger, E.S., Adee, E.A., Hinkens, E.A., Martinka, M.J., 1994. Planting date and row width effect on severity of brown stem rot and soybean productivity. $\mathrm{J}$ Prod. Agric. 7, 347-351.

Heal, O.W., Anderson, J.M., Swift, M.J., 1997. Plant litter quality and decomposition: an historical overview. In: Cadish, G., Giller, K.E. (Eds.), Driven by Nature, Plant Litter Quality and Decomposition. CAB International, Wallingford, UK, pp. 47-66.

Lee, C.D., 2006. Reducing Row Spacings to Increase Yield: Why it Does Not Always Work. Plant Management Network, St. Paul, MN, Available at www.plantmanagementnetwork.org/pub/cm/review/2006/wide.

Lueschen, W.E., Ford, J.H., Evans, S.D., Kanne, B.K., Hoverstad, T.R., Randall, G.W., Orf, J.H., Hicks, D.R., 1992. Tillage, row spacing, and planting date effects on soybean following corn and wheat. J. Prod. Agric. 5, 254-260.

Lyon, D.J., Boa, F., Arkebauer, T.J., 1995. Water-yield relations of several springplanted crops following winter wheat. J. Prod. Agric. 8, 281-286.

Nielsen, D.C., Nelson, N.O., 1998. Black bean sensitivity to water stress at various growth stages. Crop Sci. 38, 422-427.

Nielsen, D.C., Vigil, M.F., 2005. Legume green fallow effect on soil water content at wheat planting and wheat yield. Agron. J. 97, 684-689.

Nielsen, D.C., Vigil, M.F., 2010. Precipitation storage efficiency during fallow in wheat-fallow systems. Agron. J. 102, 537-543.

Oplinger, E.S., Philbrook, B.D., 1992. Soybean planting date, row width, and seeding rate response in three tillage systems. J. Prod. Agric. 5, 94-99.

Osman, A.E., Nersoyan, N., 1986. Effect of the proportion of species on the yield and quality of forage mixers, and on the yield of barley in the following year. Exp. Agric. 22, 345-351.

Palmer, V.S., Kaul, A.K., Spencer, P.S., 1989. International network for the improvement of Lathyrus sativus and the eradication of Lathyrism (INILSEL): ATWMRF initative. In: Spencer, P. (Ed.), The Grasspea: Threat and Promise. Proc. of the Intl. Net-work for the Improvement of Lathyrus sativus the Eradication of Lathyrism. Third World Medical Research Foundation, New York, pp. 219-223.

Peterson, G.A., Schlegel, A.J., Tanaka, D.L., Jones, O.R., 1996. Precipitation use efficiency as affected by cropping and tillage systems. J. Prod. Agric. 9, 180-186.

Rao, S.L.N., Adiga, P.R., Sarma, N.P.S., 1964. The isolation and characterization of $\beta$ $\mathrm{N}$-oxalyl- $\alpha, \beta$-diaminopropionic acids: a neurotoxin from the seeds of Lathyrus sativus. Biochemistry 3, 432-436.

Rao, S.C., Northup, B.K., Mayeux, H.S., 2005. Candidate cool-season legumes for filling forage deficit periods in the southern great plains. Crop Sci. 45, 2068-2074.

Rao, S.C., Northup, B.K., 2008. Planting date affects production and quality of grass pea forage. Crop Sci. 48, 1629-1635.

Sainju, U.M., Caesar-TonThat, T., Lenssen, A.W., Evans, R.G., Kolberg, R., 2007. Longterm tillage and cropping sequence effects on dryland residue and soil carbon fractions. Soil Sci. Soc. Amer. J. 71, 1730-1739.

Siddique, K.H.M., Loss, S.P., Regan, K.L., Jettner, R.L., 1999. Adaptation of cool season grain legumes in Mediterranean-type environments of south-western Australia. Aust. J. Agric. Res. 50, 375-387.

Siddique, K.H.M., Regan, K.L., Tennant, D., Thomson, B.D., 2001. Water use and water use efficiency of cool season grain legumes in low rainfall Mediterranean-type environments. Eur. J. Agron. 15, 267-280.

Singh, S.P., 1995. Selection for water-stress tolerance in interracial populations of common bean. Crop Sci. 35, 118-124.

U.S. Global Change Research Program, Global Climate Change Impacts in the U.S. Found at: http://www.globalchange.gov/publications/reports/scientificassessments/us-impacts/regional-climate-change-impacts/great-plains.

Vigil, M.F., Kissel, D.E., 1991. Equations for estimating the amount of nitrogen mineralized from crop residues. Soil Sci. Soc. Am. J. 55, 757-761.

Vigil, M.F., Nielsen, D.C., 1998. Winter wheat yield depression from legume green fallow. Agron. J. 90, 727-773. 